1990

\title{
This Gun for Hire: Dancing in the Dark of the First Amendment
}

Michael I. Meyerson

University of Baltimore School of Law, mmeyerson@ubalt.edu

Follow this and additional works at: http://scholarworks.law.ubalt.edu/all_fac

Part of the First Amendment Commons, and the Torts Commons

\section{Recommended Citation}

This Gun for Hire: Dancing in the Dark of the First Amendment, 47 Wash. \& Lee L. Rev. 267 (1990)

This Article is brought to you for free and open access by the Faculty Scholarship at ScholarWorks@University of Baltimore School of Law. It has been accepted for inclusion in All Faculty Scholarship by an authorized administrator of ScholarWorks@University of Baltimore School of Law. For more information, please contact snolan@ubalt.edu. 


\section{THIS GUN FOR HIRE: DANCING IN THE DARK OF THE FIRST AMENDMENT}

\section{MiChael I. Meyerson*}

Classified advertisements in newspapers and magazines represent a uniquely democratic access to the media for the individual. Without having to pay the thousands of dollars for full-page advertisements, buyers and sellers can purchase space for their offers for only a few dollars, yet have them seen by city-wide or nation-wide audiences. Democracy, though, breeds its own excesses, and the legal question is always how to control that excess without harming the freedom.

As befits a medium open to all, classified advertisements run the gamut of human activity, from the sale of a used automobile to employment to lonely singles looking for an "attractive, nonsmoking, athletic" mate. Unfortunately, classified advertisements also have been used as part of criminal activities, to help "buyers" locate those willing to kidnap or murder for the going rate.

Victims, or the families of victims, of these crimes facilitated by classified advertisements have sued the publisher of the advertisements for damages. Courts have been uncertain, at best, how to evaluate these lawsuits. Through an unclear mixture of tort law and commercial speech doctrine, courts have failed to announce a clear standard to guide the conduct of publishers. This article will attempt to clarify the conflicting legal standards and describe a usable test that would both protect publishers from unnecessarily onerous burdens of investigating all classified advertisements and pretect the public against the danger of the hired gun.

A duty of care should be placed on publishers only in extraordinary circumstances. For ambiguous advertisements that may reasonably imply violence, the only publishers who would be under a duty of care would be those few for whom the danger to the public was foreseeable. Specifically, a publisher would only be held liable for publishing an ambiguous advertisement if there was a history of that particular publication's advertisements being used for violent crimes. To avoid liability, such publishers could either refuse to run ambiguous advertisements or use their own editorial power to clear up the ambiguity to prevent the innuendo of illegality.

Few publishers would be affected by this standard and few advertisements would fail to see the light of day. Nonetheless, both human lives and public respect for the first amendment would be protected.

\section{ANATOMY OF AN ADVertisement}

In October and November of 1984, Soldier of Fortune magazine ran the following advertisement:

* Associate Professor of Law, University of Baltimore School of Law. 
EX-MARINES-67-69 'Nam Vets, Ex-DI, weapons specialist--jungle warfare, pilot, M.E., high risk assignments, U.S. or overseas. (404) 991-2684. ${ }^{1}$

Some of the abbreviations in this advertisement are essentially military terms of art. For example, "DI" means "drill instructor" and "M.E." means "multi-engined planes." The meaning and interpretation of some of the other phrases in the advertisement, such as "high risk assignments," are at the heart of the legal analysis.

Robert Black read this ad and telephoned John Wayne Hearn, who had placed the advertisement. Black offered Hearn $\$ 10,000$ to murder his wife. On February 21, 1985, Hearn fulfilled his part of the bargain and killed Sandra Black.

Sandra Black's mother and son sued Soldier of Fortune magazine for wrongful death, charging that the magazine was negligent in publishing the advertisement. The district court held that the correct standard for evaluating the magazine's conduct was whether the publisher "knew or should have known of the nature of the advertisement and, thus, should have foreseen the likelihood that criminal conduct would ensue."2 A jury found that the danger was indeed foreseeable and awarded the plaintiffs \$1.9 million dollars in compensatory damages and $\$ 7.5$ million in punitive damages.

On appeal, Soldier of Fortune magazine argued that the verdict and award were invalid, both as a matter of tort law and under the first amendment. The Court of Appeals for the Fifth Circuit, while mentioning the first amendment interest in commercial speech, held that the verdict was flawed because, as a matter of tort law, the district court had demanded too high a standard of conduct. The "facially innocuous" advertisement did not indicate that illegal activity was foreseeable. The publisher could not be held accountable for an ambiguous advertisement; liability would not be found without "a more specific indication of illegal intent. . . ."3

\section{ALGEBRA OF LIABIITY}

Courts that are faced with the issue of determining claims of negligence against the media must deal both with tort and first amendment issues. Once

1. Eimann v. Soldier of Fortune Magazine, Inc., 680 F. Supp. 863,864 (S.D. Tex. 1988), rev'd, 880 F.2d 830 (5th Cir. 1989), cert. denied, 110 S. Ct. 729 (1990). This is not the first reported case involving a hired gun lawsuit. That distinction belongs to Norwood v. Soldier of Fortune Magazine, Inc., 651 F. Supp. 1397 (W.D. Ark. 1987). One of the advertisements in that case read:

GUN FOR HIRE: 37 year-old-professional mercenary desires jobs. Vietnam Veteran. Discreet and very private. Bodyguard, courier, and other special skills. All jobs considered. Phone (615) 891-3306.

Id. at 1398. The victim in Norwood was shot and wounded in an attempt on his life by people hired through the advertisement. Id.

2. Eimann, 680 F. Supp. at 867.

3. Eimann, 880 F.2d at 838 . 
the standard of care is created, that standard also must survive constitutional scrutiny because it will apply to speech.

Before any liability for negligence can be imposed, it must be shown that the actor had a duty to the plaintiff. The concept of duty is intertwined with the issue of foreseeability. If a given harm is foreseeable, juries must then evaluate the proper duty of care in light of this harm. ${ }^{4}$ The publishing of a classified advertisement is obviously an "affirmative act." The question for determining what is an "unreasonable" risk of harm from that activity requires a balancing of risk and benefit associated with that activity.

According to the Restatement (Second) of Torts, an act creates an unreasonable risk of harm if the risk is foreseeable and the magnitude of the harm outweighs the "utility" of the act and the "particular manner in which it is done."s A risk may be foreseeable, even if harm will arise only through a third party's criminal conduct, when "the actor acts with knowledge of peculiar conditions which create a high risk of intentional misconduct."6

Judge Learned Hand's mathematical formula of the balancing principle stated that liability would be found only if the burden of taking adequate precautions was less than the probability of harm multiplied by the gravity of the harm. ${ }^{7}$ The valuation of the probability of harm turns on the foreseeability of that harm.

Significantly, and perhaps not coincidentally, Judge Learned Hand used virtually the identical formula to evaluate the constitutionality of regulation of speech that might lead to illegal, violent actions: "In each case [courts] must ask whether the gravity of the 'evil' discounted by its improbability, justifies such invasion of free speech as is necessary to avoid the danger."

Both the tort and constitutional balances require an evaluation of three factors. Two of these factors are identical: the gravity of the harm, and the likelihood of the harm occurring. The third factor, the one that is to be compared with the product of the other two, is often the same as well. When dealing with unprotected speech, the "invasion of free speech" imposed by government is actually the speaker's "burden of taking adequate precautions" to avoid the danger.

4. Palsgraf v. Long Island R.R. Co., 248 N.Y. 339, 162 N.E. 99 (1928). The Restatement of Torts (Second) $\S 302$ comment a (1965), states that, "In general, anyone who does an affirmative act is under a duty to others to exercise the care of a reasonable [person] . .. to protect them against an unreasonable risk of harm to them arising out of the act."

5. Restatement OF TORTS (SECOND) $\$ 291$ (1965). An alternate way of describing the test is whether "the game is worth the candle." Id. $\S 291$ comment a.

6. Id. $\S 302 \mathrm{~B}$ comment $\mathrm{e}$.

7. United States v. Carroll Towing Co., 159 F.2d 169, 173 (2d Cir. 1947). This formula was cited by the court of appeals in Eimann, $880 \mathrm{~F} .2 \mathrm{~d}$ at 835 .

8. United States v. Dennis, 183 F.2d 201, 212 (2d Cir. 1950), aff'd, 341 U.S. 494 (1951). The Supreme Court explicitly adopted the Hand formula as the appropriate standard, describing it as, "succinct and inclusive as any we might devise at this time. It takes into consideration those factors which we deem relevant, and relates their significance. More we cannot expect from words." 341 U.S. at 510. Judge, then Professor, Posner termed both the tort and speech tests "economic" formulas. R. Posner, Economic Analysis of Law, 122 \& 542 (2d ed. 1975). 
For example, in the area of defamation the Supreme Court has held that "there is no constitutional value in false statements of fact." Nonetheless, the burden of avoiding all such false statements would be too great a limitation on free speech unless speakers were given a margin for error. Thus, when discussing public figures, about whom the interest in free public discourse is greatest, liability requires "actual malice," publication with either knowledge of the false statements or serious doubts as to their validity..$^{10}$ For injured private figures, a greater burden is permitted to be placed on the speaker, and liability will be found upon simple negligence. ${ }^{11}$

The Court's explicit procedural requirements for the licensing of films reflect a similar concern. In any scheme of governmental censorship, the burden is placed on the censor to prove the film is unprotected obscenity, the censor must seek a judicial confirmation of the finding of obscenity, and all this must occur within a definite, limited time period. ${ }^{12}$ These safeguards are aimed at reducing the burden on free speech created by the prohibition of unprotected, obscene films.

Similarly, advertisements for illegal activity are unprotected, ${ }^{13}$ and the invasion of free speech imposed by a rule of liability will be the burden that is imposed on publishers to police their ads. To create the appropriate calculus for establishing media liability for classified advertisements, the gravity and likelihood of harm must be balanced against the burden placed on free speech interests. All three factors are variables, subject to change with differing circumstances.

\section{A. The Gravity of Harm}

In the case of the hired gun, the gravity of harm is great. The harm caused to third parties by murder or other violent crimes is worthy of the highest governmental concern. The court of appeals in Eimann characterized the harm as "the threat of serious harm."14 This seems a bit of an understatement for murder.

The gravity of harm can be contrasted with other classified advertisement cases where the harm suffered was of a lesser magnitude. For example, in Vaill v. Oneida Dispatch Corp. ${ }^{15}$ a maliciously placed advertisement for a "MIDDLE AGED FEMALE looking for male companionship" led to the plaintiff's receiving numerous annoying and obscene telephone calls. In Pitt-

9. Gertz v. Robert Welch, Inc., 418 U.S. 323, 340 (1974).

10. St. Amant v. Thompson, 390 U.S. 727 (1968); New York Times Co. v. Sullivan, 376 U.S. 254 (1964).

11. Gertz, 418 U.S. 323, 348-50 (1974).

12. Freedman v. Maryland, 380 U.S. 51 (1965).

13. Pittsburgh Press Co. v. Pittsburgh Comm'n on Human Relations, 413 U.S. 376, 389 (1973) (stating "Any First Amendment interest which might be served by advertising an ordinary commercial proposal . . . is altogether absent when the commercial activity itself is illegal. . . ."). 14. Eimann, 880 F.2d at 835 .

15. 129 Misc.2d 477, 493 N.Y.S.2d 414 (N.Y. Sup. Ct. 1985). 
man v. Dow Jones \& Co. ${ }^{16}$ investors lost $\$ 50,000$ due to a fraudulent advertisement in the Wall Street Journal. Neither of these rise to the level of murder, and therefore the appropriate burden, if any, to be placed on publishers to avoid these harms will be less.

One additional cause of concern with hired gun advertisernents is that the victims of these ads in no way assume the risk associated with the advertisement and cannot protect themselves against the unknown danger. By contrast, those who purchase advertised services retain at least some ability to determine the wisdom of their transactions. ${ }^{17}$ This distinction argues for greater protection of third parties than for the readers of advertisements, distinguishing hired gun cases from those involving, for example, people harmed after answering personal ads.

In considering the appropriate level of care to be placed on a publisher, courts will need to consider the harm that is threatened. The more serious the harm, as in the case of murder and other violent crime, the greater the duty of care will tend to be if there is sufficient likelihood of that harm occurring.

\section{B. Likelihood and Foreseeability of Harm}

Because other crimes had been committed using the classified advertisements in Soldier of Fortune, the court of appeals in Eimann stated that the magazine's advertisements, "presented more than a remote risk [of harm]."18 Nonetheless, the court concluded that due to the "fundamental ambiguity" of the advertisement in question, as well as the fact that there were similar advertisements with "violent themes," there was "no realistic method for gauging the likelihood that a particular ad will foster illegal activity." 19 The court concluded that a tort standard of liability whenever an advertisement "could reasonably be interpreted as an offer to engage in illegal activity" or "'might 'relate to' criminal conduct," would impose an unacceptably onerous burden on publishers. ${ }^{20}$

The court buttressed its finding by citing the important role commercial speech plays in communication of consumer information. ${ }^{21}$ In answer to the argument that there is no constitutional protection for advertisements for illegal commercial activity, the court stated that, "in the constitutional arena we have noted that the possibility of illegal results does not necessarily strip an ad of its commercial speech protection." 22

16. 662 F. Supp. 921 (E.D. La. 1987).

17. See Walters v. Seventeen Magazine, 195 Cal. App. 3d 1119, 241 Cal. Rptr. 101 (Cal. Ct. App. 1987) (teenage purchaser of advertised tampons); Pressler v, Dow Jones \& Co., 88 A.D.2d 928, 450 N.Y.S.2d 884 (App. Div. 2d Dep't, 1982) (fraudulent advertisement).

18. Eimann, 880 F.2d at 835 .

19. Id. at 836 .

20. Id. at 837 .

21. The court cited Virginia State Board of Pharmacy v. Virginia Citizens Consumer Council, Inc., 425 U.S. 748 (1976), but added, however, that it was not reaching the first amendment arguments. Eimann, 880 F.2d at 836.

22. Id. at 837 (emphasis added). 
The problem with the court's tort and constitutional analysis derives from confusion over the concept of the possible. Even Soldier of Fortune agrees that it would be liable for an advertisement that explicitly offered to commit an illegal act:23 for instance, "I will murder or kidnap. Reasonable rates." On the other hand, no one would argue that a publisher of a telephone directory would be liable for a break-in if committed by a locksmith whose advertisement "reveals nothing about that particular advertiser's willingness to commit burglaries. ..."24

The case of the hired gun falls uncomfortably between these two extremes. The court of appeals actually found that the Hearn's ad was akin to that of the innocuous-sounding locksmith. A closer look at the advertisement and the magazine, however, reveals a far more sinister offer, one that would be apparent to the reasonable reader.

First, let us isolate some of the phrases from the advertisement: "weapons specialist-jungle warfare," "high risk assignments," and "U.S. or overseas." The court of appeals held that the language was "facially innocuous" and "plausibly encompassed Hearn's professed goal of recruiting candidates for bodyguard jobs." 25 One would not be unduly skeptical to wonder why "high risk assignments" was used instead of the more obvious "bodyguard." Moreover, the addition of the phrase "jungle warfare" adds a particularly sanguinary tone to the offered service.

Additionally, the location of an advertisement helps indicate how it should be interpreted. Just as listing jobs in a "male interest" category would lead readers to expect that the advertiser is likely to discriminate, ${ }^{26}$ the placement of Hearn's ad in Soldier of Fortune helped clarify some of its potential ambiguity. Unlike the Yellow Pages, home of the locksmith's advertisement, Soldier of Fortune's advertisements have a well-earned reputation as a potential source of illegality. Historically, the magazine had published advertisements for explicitly illegal activity. ${ }^{27}$ Additionally, at least nine violent crimes had been traced to advertisements in the magazine. ${ }^{28}$ Finally, of course, the nature of the magazine is one that encourages violence, with advertisements for books entitled "Deadly Explosives: How and Why They Work" and

23. Norwood v. Soldier of Fortune Magazine, Inc., 651 F. Supp. 1397, 1398 (W.D. Ark. 1987) (stating that Soldier of Fortune contends it would only be liable for "clear and unambiguous solicitation to engage in an illegal transaction").

24. Eimann, $880 \mathrm{~F} .2 \mathrm{~d}$ at 836.

25. Id. The court noted that there was, in fact, one client who did hire Hearn for bodyguard services.

26. Pittsburgh Press Co. v. Pittsburgh Comm'n on Human Relations, 413 U.S. 376, 389 (1973).

27. Eimann v. Soldier of Fortune Magazine, Inc., 680 F. Supp. 863, 866 (S.D. Tex. 1988), rev'd, 880 F.2d 830 (5th Cir. 1989), cert. denied, 110 S. Ct. 729 (1990). See, e.g., Norwood, 651 F. Supp. at 1398 (ad states "GUN FOR HIRE . . professional mercenary desires jobs").

28. Eimann, 880 F.2d at 835 . Nine known crimes out of the 2000 classified advertisements printed by Soldier of Fortune over a 10-year period would put the reasonable publisher on notice that, unlike other publications, there was a reasonable chance that this magazine's advertisements might be used for illegal activities. 
articles such as, "Lady Killers: Affirmative Action Comes to the Assassin's World." "29

It is critical, however, that a magazine should not be penalized for the opinions it expresses. Nonetheless, context is essential for understanding the meaning of words. Just as "the consideration of the setting in which the publications were presented" has been found relevant for determining whether material is obscene,,$^{30}$ so should the context of a classified advertisement help determine its proper meaning.

Not only is this logical from a legal point of view, this is apparently how the readers of Soldier of Fortune viewed the advertisement in question. An incredible $90 \%$ of the calls received by Hearn in response to his advertisement inquired about illegal activities. ${ }^{31}$ Despite the court's analogizing, it is more than unlikely that a similar percentage of phone calls seeking assistance with illegal break-ins has been received by locksmiths advertising in Yellow Pages. Hearn reported that he received three to five calls per day from people wanting to hire him to commit murder. ${ }^{32}$ Why were all these readers able to extract a meaning from language that the court of appeals termed "facially innocuous" and "fundamentally ambigu[ous]"? The answer lies in the difference between possibility and likelihood.

Without question, as the court of appeals reasoned, all of life's activities create risks, and the "range of foreseeable misuses of advertised products and services is as limitless as the forms and functions of the products themselves." ${ }_{33}$ However, in the words of Justice Cardozo, "The law is not indifferent to considerations of degree." 34 Where an advertisement contains language that reasonably could be interpreted as offering to commit a violent illegal act, and where a publication has run similar advertisements in the past which resulted in crimes of violence, the likelihood of harm far exceeds that of the normal advertisement. Recognizing the heightened degree of risk posed by such an advertisement, however, should not cause fear that peanut butter advertisements will be banned because "someone might someday throw a jar at the presidential motorcade." ${ }^{35}$

The Constitution similarly does not require certainty before commercial speech can be regulated. The court of appeal's statement that "the possibility of illegal results" is insufficient to permit the regulation of commercial speech

29. SOLdIER OF Fortune, Feb. 1990 , at $75 \& 24$.

30. Ginzburg v. United States, 383 U.S. 463, 465 (1966); see generally Splawn v. California, 431 U.S. 595 (1977).

31. Eimann, 680 F. Supp. at 866-67. Apparently, neither party questioned the truthfulness of this statement. For the sake of legal argument, at least, its accuracy should be assumed.

32. Id. Hearn apparently did not say for how many days these calls continued.

33. Eimann, 880 F.2d at 838 .

34. A.L.A. Schecter Poultry Corp. v. United States, 295 U.S. 495, 554 (1935) (Cardozo, J., concurring).

35. Eimann, 880 F.2d at 837 (quoting Dunagin v. City of Oxford, 718 F.2d 738, 743 (5th Cir. 1983). 
misreads Pittsburgh Press Co. v. Pittsburgh Commission on Human Relations. ${ }^{36}$

In Pittsburgh Press, the Supreme Court permitted the city's Commission on Human Relations to prevent a newspaper from publishing employment advertisements under columns titled, "Jobs-Male Interest" and "Jobs-Female Interest." The illegal activity, which such columns threatened, was prospective employers using the columns to discriminate on the basis of sex in hiring. The Court did not require certainty that illegal activity would occur. It was sufficient that such an advertiser "is likely to discriminate. . . ."37

The comparison to the hired gun cases is especially close because the ads in Pittsburgh Press did not expressly mention that laws would be broken and that only one sex would be hired. In fact, the newspaper published a disclaimer stressing that the columns were only used to aid employees, and that employers should be assumed not to discriminate illegally. ${ }^{38}$ Nonetheless, the Court found that the lack of an express declaration of illegal intent would not save the columns: "The illegality in this case may be less overt, but we see no difference in principle here." 39

There is also no difference in principle between a subtle and an overt hired gun ad. As long as the ads "convey essentially the same message," 40 and there is a finding that those who use the advertisements are "likely" to commit violent crimes, the first amendment will afford them no shelter.

\section{The Burden on Free Speech of Avoiding the Harm}

The court of appeals struck down the award to Sandra Black's mother and son because it perceived that the burden placed on publishers to avoid liability was too onerous. The court stated that, under a standard of liability for language that "could reasonably be interpreted" as offering illegality, the only way for a publisher to preverit liability if faced with an ambiguous advertisement is that "he must reject all such advertisements."

36. 413 U.S. 376, 389 (1973).

37. Id. at 388 (emphasis added). See also Posadas de Puerto Rico Assoc. v. Tourism Co. of Puerto Rico, 478 U.S. 328, 343 (1986) (stating that "the risks associated with casino gambling were significantly greater than those associated with the more traditional kinds of gambling. ...") (emphasis added).

38. The disclaimer read:

Jobs are arranged under Male and Female classifications for the convenience of our readers. This is done because most jobs generally appeal more to persons of one sex than the other. Various laws and ordinances-local, state, and federal, prohibit discrimination in employment ... unless sex is a bona fide occupational requirement. Unless the advertisement itself specifies one sex or the other, job seekers should assume that the advertiser will consider applicants of either sex in compliance with the laws against discrimination.

Pittsburg Press, 413 U.S. at 381 n.7.

39. Id. at 388.

40. Id.

41. Eimann v. Soldier of Fortune Magazine, Inc., 880 F.2d 830, 838 (5th Cir. 1989), cert. denied, 110 S. Ct. 729 (1990) (emphasis in original). Indeed, Soldier of Fortune has, at least temporarily, suspended its acceptance of all personal service advertisements. SOLDIER OF FORTUNE, Feb. 1990 , at 92 . 
The court concluded that such a requirement would diminish the informational benefits supplied by advertisements. Additionally, the court stated that a publication's "editorial content" would suffer from "loss of revenue .. . if publishers were required to reject all ambiguous advertisements."

In analyzing the "burden" to be placed on publishers, two different types of burdens must be considered: a) the actual burden on the publisher, i.e., what action he or she must take to avoid liability; and b) the burden on first amendment values such required action would impose. The court of appeals ignored some less onerous actions that could have been taken by Soldier of Fortune and overestimated the extent of the invasion of free speech caused by either that lesser burden, or any requirement, concerning classified advertisements.

The less onerous path for a publication, such as Soldier of Fortune, can be seen if the advertisements are divided into three categories: those explicitly proposing illegal transactions, those totally free from all but the most exaggerated innuendo (the jar of peanut butter or the helpful locksmith), and those containing what the court of appeals termed, "suspicious, ambiguous" language. In the first category, no significant burden at all would arise from a requirement that publications not publish advertisements for explicitly illegal activity. Upon reading the ad, the publisher would know of the danger. Especially presuming that most advertisements are not in this category, the burden of refusing such advertisements is slight.

The second category can be published safely. An advertisement that contains no hint to the reasonable reader of illegal portent cannot be the source of negligence.

For the third category, advertisements with suspicious and ambiguous language, a publisher could indeed refuse such ads to avoid liability. But there is an alternative for the publisher; rather than ban ambiguous advertisements, simply clear up the ambiguity. If "high risk assignments" is supposed to mean "bodyguard jobs," say so. The publisher on notice of a "more than remote risk" of violent illegality, should require the use of more explicit, less suggestive language. It is not too great a burden to require a publisher with a history like that of Soldier of Fortune to devise language that would avoid the ambiguity and prevent the use of code words that result in a $90 \%$ understanding that criminality is afoot.

Publications historically have refused to carry advertisements that contain subtle suggestions of illegality. For example, the Boston Globe refused to run an advertisement for an "escort service." 43 Similarly, the New York Times refused to publish an advertisement for a vacation resort that contained the language "selected clientele" because the phrase "is merely a cloak and disguise and an indirect means to hide discrimination."

42. Eimann, 880 F.2d at 837.

43. PMP Assocs., Inc. v. Globe Newspaper Co., 321 N.E.2d 915 (Mass. 1975).

44. Camp-of-the-Pines, Inc. v. New York Times Co., 184 Misc. 389, 398, 53 N.Y.S.2d 475, 484 (N.Y. Sup. Ct. 1945). 
the newspaper to substitute the less suggestive phrase "congenial following."

Of course, there is a fundamental difference between a publication voluntarily reviewing its advertisements for implied illegality and the government requiring such a review. Nonetheless, the ability and practice of such publications is relevant to show that the act of review itself would not create an untenable burden.

In sum, there would be no obligation on a publisher to police advertisements not explicitly offering illegal services unless the publication had a known history of its ads being used for such services. If there is such a history, such that the risk is foreseeable, then publishers would be liable for the harm caused by negligent publication of advertisements for illegal activity. The appropriate duty of care would require such publishers to avoid language in advertisements that might reasonably be understood to invite criminal behavior. Publishers could refrain from publishing such advertisements. Alternatively, such language could be avoided if the publisher mandated which language is used by its advertisers (requiring "bodyguard" instead of "high risk assignments," for example). If uniform, innocuous language were used, the publisher would not be negligently facilitating the commission of violent crimes.

This standard of reasonable care also must be evaluated as a second type of burden, an invasion into free speech caused by imposing liability for classified advertisements. Two district courts mistakenly have assumed that because post-publication liability does not constitute a classic prior restraint, it cannot seriously impinge expression. ${ }^{45}$ Such reasoning cannot survive New York Times Co. v. Sullivan, ${ }^{46}$ where the Court held that speech that cannot be criminally prohibited is also beyond the reach of civil law. As the Court noted, "The fear of damage awards under ... [libel law], may be markedly more inhibiting than the fear of prosecution under a criminal statute." 47 Thus, the analysis must regard the possibility of post-publication liability as imposing a burden on a speaker.

That conclusion, though, does not end the inquiry. For the key question is "What kind of speech is being burdened?". This issue does not revolve around political speech, as in New York Times Co. v. Sullivan, ${ }^{48}$ or even fiction and drama, as in Olivia N. v. National Broadcasting Co. ${ }^{49}$ Instead,

45. See Eimann, $680 \mathrm{~F}$. Supp. at 865 (stating "Plaintiffs do not seek to regulate commercial speech but only to recover damages for negligent publication."); Norwood v. Soldier of Fortune Magazine, Inc., 651 F. Supp. 1397, 1400 (W.D. Ark. 1987) (stating "[Plaintiff] is not attempting to have defendant enjoined from exercising its rights to run advertisements. . . . Instead, he is simply asking that a jury, after a trial, award him damages for the consequences of those advertisements.").

46. 376 U.S. 254 (1964).

47. New York Times Co. v. Sullivan, 376 U.S. 254, 277 (1964) (emphasis added).

48. Id. at 254 (advertisement discussing police treatment of civil rights demonstrators).

49. 126 Cal. App. 3d 488, 178 Cal. Rptr. 888 (Cal. Ct. App. 1981) (depiction of violence in television drama, Born Innocent). 
the speech involved in the hired gun cases is quintessential commercial speech, "which does no more than propose a commercial transaction." 50

Commercial speech is protected by the first amendment because it provides information to enhance the making of intelligent, well-informed economic decisions..$^{\text {st }}$ Nonetheless, commercial speech may be regulated in ways in which political or other noncommercial speech may not: "[W]e [the Court] ... have afforded commercial speech a limited measure of protection, commensurate with its subordinate position in the scale of First Amendment values." \$2

The Supreme Court has announced a multipart test for analyzing restrictions on commercial speech. First, only speech concerning lawful activity is protected by the first amendment. If speech is protected, it can be regulated if the governmental interest is substantial, the regulation directly advances that interest, and there is a "reasonable fit" between the governmental goals and the means chosen to advance those goals. ${ }^{53}$

Although hired gun advertisements concern illegal activity, any tort rule of liability inevitably will affect some perfectly legal advertisements as well. When liability looms, speakers tend to avoid speech "at the margins" in selfdefense. $^{54}$ Thus, the rule of liability must withstand the scrutiny of the rest of the test.

Nonetheless, a negligence rule of liability passes muster. The governmental interest in preventing violent crimes is certainly "substantial," and a rule that discourages the publication of advertisements for the commission of crimes directly advances that interest. The question remains whether there is a "reasonable fit" between the two.

The Supreme Court in Board of Trustees of the State University of New York v. Fox" rejected the use of the "least restrictive means test" for determining the validity of governmental regulation of commercial speech. Instead, the Court held that "reasonable fit" required the government to use means narrowly tailored to achieve the desired objective. ${ }^{56}$ As with defamation of private persons, ${ }^{57}$ the negligence standard of tort law embodies the necessary

50. Virginia State Bd. of Pharmacy v. Virginia Citizens Consumer Council, Inc., 425 U.S. 748, 762 (1976). See Pittsburgh Press Co. v. Pittsburgh Comm'n on Human Relations, 413 U.S. 376,385 (1973) (stating "Each [advertisement] is no more than a proposal of possible employment. The advertisements are thus classic examples of commercial speech.").

51. Virginia Pharmacy, 425 U.S. at 765.

52. Ohralik v. Ohio State Bar Ass'n, 436 U.S. 447, 456 (1978).

53. See Central Hudson Gas \& Elec. Co. v. Public Service Comm'n of New York, 447 U.S. 557, 556 (1980); Board of Trustees of the State Univ. of New York v. Fox, 109 S. Ct. $3028,3034-35$ (1989).

54. See, e.g., New York Times Co. v. Sullivan, 376 U.S. 254, 279 (1964) (stating that speakers "tend to make only statements which 'steer far wider of the unlawful zone."' (quoting Speiser v. Randall, 357 U.S. 513, 526 (1958)).

55. 109 S. Ct. 3028 (1989).

56. Board of Trustees of the State Univ. of New York v. Fox, 109 S. Ct. 3028, 3035 (1989).

57. Gertz v. Welch, 418 U.S. 323 (1974). Of course, when the interest in free speech is greater, as concerning public figures, the negligence standard is insufficient and the higher standard of New York Times Co. v. Sullivan is needed. 
balance to meet the constitutional requirements for commercial speech. Although such a standard would not be sufficient where more highly protected speech is involved, ${ }^{58}$ the burden placed on commercial speech is a permissible one.

One particular characteristic of the advertisements affected by the negligence standard guarantees that there would be, at most, a minimal harm to free speech interests. The test only applies to "ambiguous" advertisements..$^{59}$ The informational value of commercial speech must be at its nadir with ambiguous advertisements. Commercial speech is protected because it is indispensable for the making of "intelligent and well informed" commercial choices through the "dissemination of information as to who is producing and selling what product, for what reason, and at what price." 60 An ambiguous advertisement, one that is uncertain as to meaning and may be plausibly construed to mean either illegal or legal activity, ill serves the making of a "well informed" choice. 61 A requirement that "suspicious, ambiguous" language in advertisements be replaced with more explicit, less suggestive language furthers, rather than inhibits, the free speech interest served by the commercial speech doctrine.

Finally, a concern that loss of advertising revenue would injure noncommercial speech is inappropriate. The court of appeals warned that "the publication's editorial content would surely feel the economic crunch from loss of revenue that would result if publishers were required to reject all ambiguous advertisements." 62 The antitrust laws may limit the income that a newspaper can earn, yet enforcement of those laws does not result in an "unconstitutional crunch" on the content it publishes. ${ }^{63}$ Similarly, by requiring a publisher to act reasonably to avoid foreseeable risk, the tort law only "applies to a publisher what the law applies to others." 64

\section{CONCLUSION}

Classified advertisements play an important role in the dissemination of information, both by providing commercial information and by offering economic support to the speech of publications. A proper tort standard should leave the vast majority of those publishing classified advertisements unaffected.

58. See Olivia N. v. National Broadcasting Co., 126 Cal. App. 3d 488, 493, 178 Cal. Rptr. 888, 892 (1982); Zamora v. Columbia Broadcasting System, 480 F. Supp. 199 (S.D. Fla. 1979).

59. See supra text accompanying notes $42-43$.

60. Virginia State Bd. of Pharmacy v. Virginia Citizens Consumer Council, Inc., 425 U.S. 748,762 (1976).

61. Cf. Texas v. Johnson, 109 S. Ct. 2533, 2553 (1989) (Rehnquist, C.J., dissenting) (saying that, in terms of communicative effect, flag burning is "equivalent of an inarticulate grunt.").

62. See supra note 42.

63. See, e.g., Lorain Journal Co. v. United States, 342 U.S. 143 (1951); Associated Press v. United States, 326 U.S. 1 (1945).

64. Lorain Journal, 342 U.S. at 155-56. 
The violent misuse of classified advertisements, though, must be curbed. The duty of care proposed by this article would only be triggered by a known history of violent, criminal misuse of a particular publication's classified advertisements. For those few publishers for whom this showing was met, a duty to use reasonable means to prevent the solicitation of further criminal activity would be imposed. Accordingly, those advertisements that explicitly offered illegal transactions would be barred, and those advertisemențs reasonably suggesting illegality would need to be either banned or rephrased so as to avoid the ambiguity and impermissible innuendo.

This standard would put publishers on notice as to what course of behavior would avoid unreasonable risk of harm. It also would prevent the transformation of the enforcement of the first amendment into a high risk assignment. 